\title{
Effect of Government Taxes on Nigerian Unemployment
}

\author{
${ }^{1}$ Ogunmakin, Adeduro Adesola \\ Department of Accounting, Faculty of Management Sciences, Ekiti State University, Ado Ekiti, Ekiti State, \\ Nigeria
}

\begin{abstract}
Taxes do not only provide sustainable revenue for government to carry out its activities and provide development to its citizens, it also puts citizens in the role of stakeholders who are directly contributing to national development. In this way, wealth and employment opportunities can be created for those who are currently outside the tax net, due to low or no income, so, that they in turn also earn income on which taxes are paid and the circle of growth and development in the economy is sustained. It was based on this premise that, this study sought to examine the effect of government taxes on Nigerian unemployment, in doing this, the weighted least square regression techniques was utilised. The result showed that a positive relationship exist between unemployment, company income tax and custom and excise duty, while a negative relationship exist between the unemployment, petroleum profit tax and value added tax. The study therefore recommended that proper and adequate attention should be given to revenue generated through company income tax and custom and excise duty to reduce waste and enhance productivity towards job generations in Nigeria.
\end{abstract}

Keywords: Unemployment, Taxes \& Tax Evasion and Avoidance

\section{Introduction}

Taxes are fees charged or levied by the government on a product, income, or activities. If it is levied directly on personal or corporate income, it is called a direct tax. If it is levied on the price of goods or services, then it is called indirect taxes. The main reason for taxation is to finance government expenditure and to redistribute wealth (Worlu \& Emeka, 2012). It has observed over the years that income tax revenue has generally been grossly understated due to improper tax administration arising from under assessment and inefficient machinery for collection (Okafor, 2012). He further stated that, income tax is levied on incomes such as salaries, business profit, interest, dividend, commission, royalties and rent. It may also be charged on capital gains and petroleum profits. Taxation yields very substantial revenue to government. Therefore, it has a bearing on the Gross Domestic Product (GDP) which is the standard indicator for measuring the economic wellbeing of a nation. The nature and level of taxes vary according to the economic policies adopted by the various tax authorities. Intense advocacy for better tax incentives in many countries is a clear indication of growing concern for economic growth and sustainable development. These tax holiday, capital allowances, tax-payers' right of election, re-investment allowances, investment tax credit, interest subsidy, and export processing zone (EPZ) incentives. They are expected to attract more investments, which would ultimately translate to higher future production in the economy. Much as the impact of tax incentives on productivity, employment, and economic growth has been examined extensively; evaluation of the impact of tax incentives on corporate financial performance is still relatively limited in literature Ohaka \& Agundu (2012).

It was further stated by Worlu \& Emeka (2012) that tax revenue mobilisation is a source of financing developmental activities in less-developed economies. It has also been a difficult issue primarily because of various forms of resistance, such as tax evasion, tax avoidance and corrupt practices. These activities are considered as sabotaging the economy and are readily presented as reasons for the underdevelopment of the nation. According to Ogbonna (2007) taxation is a very powerful tools of economic reform and a major players in every economy of the world. It is never static but dynamic and should reflect current realities prevailing in the economy. He further stated that a good taxation system offers itself as one of the most effective means of mobilising nations' internal resources and it lends itself to creating enabling and conducive environment to the promotion of economic growth and development. Employment growth is a primary economic development goal of most small communities. Most jobs generally mean more residents, more spending at local businesses, and more tax revenue for government. Community leaders generally are well aware of the immediate and long term benefits resulting from employment growth (David, 2001).

Growth is one sector of the economy will not automatically translate into benefits for the poor: much will depend on the profile of growth, its employment or productivity, the sectoral location of the poor, and the extent of mobility across sectors and for employment intensive growth to translate into poverty reduction it must occur in a more productive sector, while less productive sector may require productivity intensive growth to ensure a decline in headcount poverty (Hull, 2009). It was based on the aforementioned that the World Bank (1997) posited that, impact of growth on poverty is seen as depending on the extent to which growth generate 
employment and good earning opportunities. However, if employment growth is achieved at the expense of wage reduction, it may have a meager impact on poverty.

According to Oyedele (2012), taxes provide government revenue and those who pay them have a stake in the system and in how government spends the money. He further stated that, taxes are essential to economic and social development and there is no doubt about the need for and benefit of taxation.

\section{Statement of the Problem}

Taxes do not only provide sustainable revenue for government to carry out its activities and provide development to its citizens, it also puts citizens in the role of stakeholders who are directly contributing to national development. In reciprocation therefore, the Nigerian tax system should be utilised by government as a sustainable platform for ensuring growth in the Nigerian economy. In this way, wealth and employment opportunities can be created for those who are currently outside the tax net, due to low or no income, so, that they in turn also earn income on which taxes are paid and the circle of growth and development in the economy is sustained in this manner (Aimurie, 2012). It is based on the above premise that the study sought to examine the effect of government taxes on Nigerian unemployment using time series data.

\section{Objective of the Study}

According to Worlu \& Emeka (2012), the use of tax as an instrument of fiscal policy to achieve economic growth in most develops countries cannot be reliable because of dwindling level of revenue generation. They further stated that in Nigeria, the contributions of tax revenue has not been encouraging, thus expectations of government are being cut short. Corruption, tax evasion, tax avoidance and haven indicators are strongly associated with low revenue. Therefore, the specific objective of this study is to look at the extent of relationship that exists between the government taxes and unemployment crises in Nigeria.

\section{Research Hypotheses}

$\mathrm{H}_{0}$ : $\quad$ There is a relationship between government taxes and unemployment in Nigeria.

$\mathrm{H}_{1}$ : There is no relationship between government taxes and unemployment in Nigeria.

\section{Review of Literature}

In every government set-up, there is an expectation that, citizens are to contribute part of their earnings as tax to the development of the nation. The value collected is to be utilised and manage well. The board of Inland Revenue is mandated to come-up with the estimate and ensure that target has been achieved. Managing the tax will in turn play a great role towards economic growth of any nation. This is because, tax is part of the nation's source of income and it is from this revenue that the government used in providing goods and services. Therefore, if tax is well managed, it will impact to the nation's development. Tax management in this context refers to the way and manner upon which the Board of Inland Revenue is able to raise the expected amount of revenue and manage it to the extent that at the end it will be impacted on the economy of the nation (Ibrahim, 2011). He also stated that taxation plays a greater role in generating revenue to the nations' development. In fact, according to Dandago \& Alabede (2001) cited by Ibrahim (2011) taxations can also be used as instrument for economic stabilisation and tools for government fiscal policy regulations. Though, Worlu \& Emeka (2012) posited that the use of tax as an instrument of fiscal policy to achieve economic growth in most develops countries cannot be reliable because of dwindling level of revenue generation. He further stated that in Nigeria the contributions of tax revenue has not been encouraging, thus expectations of government are being cut short. Corruption, tax evasion, tax avoidance and haven indicators are strongly associated with low revenue.

A tax system offers itself as one of the most effective means of mobilising a nations internal resources and it lends itself to creating an environment conducive to the promotion of economic growth (Ogbonna \& Ebimobowei, 2012). According to Sanni (2007) cited by Okafor (2012) tax is an instrument of social engineering, to stimulate general and /or sectoral economic growth. In that regard, taxation could have a positive or negative effect on both individual and on government. To the individual, low income tax rate constitute an incentive to work or save, while high income tax rate represents a disincentive to work or save. To the government, high tax rates provides the most reliable, important and dominant source of government revenue, for promoting the economic development of the nation. The vitality and necessity of tax prevail in the reality that it provides income for the government. Without such income, government will be powerless to carry out important ventures that cannot be shouldered by individuals on their own (Ohaka \& Agundu, 2012). The major source of government revenue in any country is from taxation. Any government, that really want to succeed and fulfill its economic, legal, political, and technological objectives most ensure that its taxation system is not only expansive but rather possesses the principles of equity, certainty, convenience, simplicity, neutrality and efficiency (Ogbonna, 2007). He also went further to state that taxes are not paid in exchange for some direct or immediate commensurate benefits or rewards to the tax payer from the government. 
Essentially, every tax must have the following basic concepts and attributes:

1. It must be backed by law for it to be enforceable.

2. It must be legally levied by a government upon income of persons, investments, properties, trustees and profits of companies.

3. It must be a system of compulsory payments by individuals and companies to relevant internal and Inland Revenue authorities at the state, local or federal government levels.

4. The payment should usually be in monetary term. It must be payment for which there is no direct benefit or specific reward from the government to the tax payer.

5. It must be for fiscal purposes (e.g. as a source of public revenues to be used for governmental expenses in respect of socio-economic development and other public purpose).

In essence, the foregoing concepts and attributes are the bedrock and essential elements upon which are successful tax system is based. Other sources of government revenue are devoid of the above attributes, especially the compulsory nature of taxation (Ogbonna, 2007).

\section{Basic Organs of Tax Administrations in Nigeria \\ i. The Federal Tax Authority \\ ii. The State Tax Authority \\ iii. The Local Government Tax Authority}

\section{Federal Government Taxes in Nigeria}

The federally collectable taxes in Nigeria according to Okafor (2012) include the petroleum profit tax (PPT), the company's income tax (CIT), customs and exercise duty and value added tax (VAT).

Anyanfo (1996) cited by Obonna \& Ebimobowei (2012) stated that the principle of taxation means the appropriate criteria to be applied in the development and evaluation of tax structure. Such principles are essentially an application of some concepts derived from welfare economics. In order to achieve the broader objectives of social justice, the tax system of a country should be based on sound principles of equity, certainty, convenience, economy, simplicity, productivity, flexibility and diversity.

Equity principle: states that every tax payers should pay the tax in proportion to his income.

Certainty principle: of taxation states that a tax which each individual is bound to pay ought to be certain, not arbitrary. The time of payment, the manner of payment, the quantity to be paid ought to all be clear and plain to the contributor and every other person Bhartia (2009) cited by Ogbonna \& Ebimobowei (2012).

Convenience principle: states that the time and manner should be convenient to the taxpayer. According to Anyanfo (1996) cited by Ogbonna \& Ebimobowei (2012), this principle of taxations provides the rationale for Pay-As-You-Earn (PAYE) system of tax payable of tax collection.

Economy principle: states that every tax should be economical for the state to collect and the tax payer to pay.

Productivity principle: states that a tax should be productive in the sense that it should bring large revenue which should be adequate for the government in all parts of the globe continuously employ tax reforms.

Simplicity principle: states that the tax should be plain, simple and intelligible to common taxpayer. Anyanfor (1996) cited by Ogbonna \& Ebimobowei (2012) argue that there should be no hidden agenda in the tax law.

Flexibility principle: implies that there should be no rigidity in taxation. Diversity principle of taxation states that there should be different variety of taxes. Bahartia (2009) cited by Ogbonna \& Ebimobowei (2012), argue that it is risky for a state or nation to solely depend upon too few a source of public revenue.

Taxation is recognised as a very important tool for national development and growth in most societies, and one of the major indices by which development and growth can be measured in any society is the amount of wealth, which is created by economic activities undertaking in that society (Aimurie, 2012). He further stated that taxes do not only provide sustainable revenue for government to carry out its activities and provide development to its citizens, it also puts citizens in the role of stakeholders, who are directly contributing to national development. In reciprocation therefore, the Nigerian tax system should be utilised by government as a sustainable platform for ensuring growth in the Nigerian economy. In this way, wealth and employment opportunities can be created for those who are currently outside the tax net, due to low or no income, so, that they in turn also earn income on which taxes are paid and the circle of growth and development in the economy is sustained in this manner. He also mentioned that taxation play a very important role in the wealth and employment creations in Nigeria economy in the following ways: 
i. Stimulating growth in the economy, by increase trade and economy activities. In this regards tax revenue should be used to provide basic infrastructure such as power, roads, transportation and other infrastructure which would facilitate trade and other economic activities.

ii. Stimulating domestic and foreign investment, where the tax system creates a competitive edge for investments in the economy, local investments would be retained in the industry, while also attracting foreign investments. Increased investment would generate employment and provide wealth in the hands of individuals.

iii. Revenue generated from taxes can also be applied directly to identified sectors of the Nigeria economy to stimulate such sectors. In this regard, the sector most be those which have potential for creating employment, developing the economy and creating wealth for the greater benefit of citizens and government of the nation.

iv. Revenue earned from taxes can be used to develop effective regulator systems, strengthen financial and economic structures and address market imperfection and other distortions in the economic sector. Taxes realised from specific sectors of the economy can be channeled back to those sectors to encourage their continued growth and development.

v. Income redistribution, whereby tax revenue realised from high income earners is used to provide public infrastructure and utilities to the lowest income earners. Taxes may also be used to create a social security net for short and long terms relief to indigent members of the society and other classes of persons who may require such intervention by the government.

Tax system shall remain responsive to internal and external developments in the Nigerian economy and shall not be allowed to become static or obsolete. In this regard, it shall be the responsibility of the executive arm of government, (which is empowered to manage the fiscal affairs of the nation), to ensure that tax rates are responsive to fiscal and economic developments within and outside the Nigerian economy (Aimurie, 2012).

\section{Research Design}

\section{Methodology}

The time series data on the dependent variable (unemployment) as well as the explanatory variables namely petroleum profit tax, company income tax, custom and excise duty and value added tax based on the research work of (Okafor, 2012), (Aimurie, 2012), ( Ogbonna \& Ebimobowen, 2012) \& (Dandago \& Alabede, 2011). Using the framework on tax revenue generation and Nigerian economic development, Okafor (2012) specifies a model as follows:

$$
\begin{aligned}
& G D P= f(P P T, C I T, C E D, V A T) \\
& \text { where: } \\
& \text { GDP represent gross domestic product } \\
& \text { PPT }=\text { petroleum profit tax } \\
& \text { CIT }=\text { company income tax } \\
& \text { CED }=\text { customs and exercise duty } \\
& \text { VAT }=\text { value added tax }
\end{aligned}
$$

The study shall adapt the model substituting as following with multiple equations and different ways of capturing unemployment.

$$
\begin{aligned}
& \text { Une }=f(P P T,C I T, C E D, V A T) \\
& \text { where }: \\
& \text { Une }=\text { Unemployment } \\
& \text { GDP represent gross domestic product } \text { PPT }=\text { petroleum profit tax } \\
& \text { CIT }=\text { company income tax } \\
& \text { CED }=\text { customs and exercise duty } \\
& \text { VAT }=\text { value added tax }
\end{aligned}
$$

The weighted least square regression techniques was utilised, the relationship was further subjected to complementary statistical tests using Statistical Package for Social Sciences (SPSS). 
Regression Model

\section{Results and Discussion}

\begin{tabular}{|l|r|r|r|r|r|r|}
\hline & \multicolumn{2}{|c|}{ Unstandardised Coefficients } & \multicolumn{2}{c|}{ Standardised Coefficients } & $\mathrm{t}$ & Sig. \\
\cline { 2 - 7 } & $\mathrm{B}$ & Std. Error & \multicolumn{1}{c|}{ Beta } & \multicolumn{1}{c|}{ Std. Error } & \multicolumn{1}{c|}{ B } & Std. Error \\
\hline PETROLPT & -1.028 & 1.067 & -.199 & .207 & -.964 & .363 \\
COMPINT & 50.928 & 19.174 & 2.114 & .796 & 2.656 & .029 \\
VALUADT & -66.385 & 27.562 & -2.490 & 1.034 & -2.409 & .043 \\
CUSEXDT & 61.434 & 13.535 & 1.593 & .351 & 4.539 & .002 \\
\hline
\end{tabular}

The fitted regression model for this research work is given as:

$$
N U E=2.11 C I T+1.59 C E D-0.20 P P T-2.49 V A T
$$

The result showed that a positive relationship exist between unemployment, company income tax and custom and excise duty, while a negative relationship exist between the unemployment, petroleum profit tax and value added tax. It was also discovered that a percentage change in the company income tax and custom and excise duty will leads to 211 and 159 percentage increase respectively on the National unemployment. However, a percentage change in petroleum profit tax and value added tax will lead to 20 and 249 percentage decrease respectively in the level of unemployment. Thus company income tax and custom excise duty policy have a negative impact on the state of Nigerian unemployment which calls for an urgent review and Nigerian government attention.

The test for significant of the parameter estimated for the purpose of this research work was carried out using the probability value of $0.02,0.04$, and 0.00 for company income tax, value added tax, and custom and excise duty respectively. They are statistically significant because they are less than the probability of the error margin (0.05) allowed in the estimation. The result implies that the explanatory variables are desirable for determine the state of unemployment in Nigeria.

\begin{tabular}{|l|r|}
\hline \multicolumn{1}{|c|}{ Muitiple R } & .995 \\
R Square(a) & .990 \\
Adjusted R Square & .985 \\
Std. Error of the Estimate & 1696386528. \\
& 943 \\
Log-likelihood Function Value & -185.680 \\
\hline
\end{tabular}

The test for the significant of the model was done using the adjusted R-square value which is the proportion of variation in the response variable that can be explained by the explanatory variables.

Based on the results of the analysis, the adjusted R-square value is 0.985 . This implies that 98.5 percentage changes in the level of unemployment in Nigeria can be explained by changes in company income tax, custom and excise duty, petroleum profit tax and value added tax.

\begin{tabular}{|c|c|c|c|c|c|}
\hline & $\begin{array}{l}\text { Sum of } \\
\text { Squares }\end{array}$ & df & Mean Square & $\mathrm{F}$ & Sig. \\
\hline Regression & $\begin{array}{r}22989526745 \\
91637000000 \\
.000\end{array}$ & 4 & $\begin{array}{r}57473816864790 \\
9000000.000\end{array}$ & 199.719 & .000 \\
\hline Residual & $\begin{array}{r}23021818044 \\
626950000.0 \\
00\end{array}$ & 8 & $\begin{array}{r}28777272555783 \\
68000.000\end{array}$ & & \\
\hline Total & $\begin{array}{r}23219744926 \\
36264000000 \\
.000(a)\end{array}$ & 12 & & & \\
\hline
\end{tabular}

The overall significant of the model fitted for the research work was carried out using the probability of F-statistics and from the results, the probability of F-statistic (0.000) is less than the probability of the error margin (0.05) allowed in the estimation. Therefore, the entire model is statically significant and it is appropriate for the determination of the level of unemployment situations in Nigeria.

\section{Concluding Remarks}

This study investigated the effect of government taxes on Nigerian unemployment. The regression results for the models revealed that there exists a positive relationship between unemployment, petroleum profit 
tax (PPT), and value added tax (VAT) while company income tax (CIT) and custom excise duty (CED) portray a negative relationship to Nigerian unemployment situations respectively. The result of the analysis shows that $1 \%$ improvement/increment in petroleum income tax and value added tax will lead to $20 \%$ and $249 \%$ reduction respectively on the Nigerian unemployment situation. Hence, this shows the influence of tax revenue generation through petroleum profit tax and value added tax in Nigeria, while $1 \%$ increment in company income tax and custom and excise duty leads to $211 \%$ and $159 \%$ increment on the unemployment situations in Nigeria. Therefore, the research recommended that proper and adequate attention should be given to revenue generated through company income tax and custom and excise duty to reduce waste and enhance productivity towards job generations in Nigeria.

\section{References}

[1]. Aimurie, I. (2012). Taxation as a tool for wealth and employment creation. Tax Justice Network-Africa. Nairobi, Kenya: Bright Wood Apartments.

[2]. Anyanfor, A. M. O. (1996). Public finance in a developing economy: The Nigerian case. Department of Banking and Finance, University of Nigeria, Enugu Campus, Enugu, Nigeria.

[3]. Bhartia, H. L. (2009). Public finance. (14 ${ }^{\text {th }}$ Edition). New Delhi: Vikas Publishing House PVT Ltd.

[4]. David, L. B. (2001). Employment generation strategies for small Towns: An Overview of Alternatives. REDRL Research Report. Regional Economic Development Research Laboratory, Clemson, SC 29634-0355.

[5]. Hull, K. (2009). Understanding the relationship between economic growth, employment and poverty reduction. Promoting Pro-Poor Growth: Employment- OECD, 2009.

[6]. Ibrahim, Y. (2011). The impact of tax management on the economic growth of Kano State. M.Sc. thesis work: Department of Accounting \& Finance, Ahmadu Bello University, Zaria.

[7]. Ogbonna, G. N. \& Ebimobowei, A. (2012). Impact of tax reforms and economic growth of Nigeria: A time series analysis. Maxwell Scientific Organisation: Research Journal of Social Sciences. 4(1): 62-68. ISSN: 2041-3246.

[8]. Ogbonna, G. N. (2007). Burning issues and challenges of the Nigerian tax systems with analytical emphasis on Petroleum profit tax.

[9]. Ohaka, J. \& Agundu, P. U. C. (2012). Tax incentives for industry synergy in Nigeria: A pragmatic proprietary system advocacy. An International Multidisciplinary Journal, Ethiopia. 6(3): 26. ISSN 1994-9057.

[10]. Okafor, R. G. (2012). Tax revenue generation and Nigeria's economic development. European Journal of Business and Management. 4(19). ISSN 2222-1905.

[11]. Oyedele, T. (2012). Keeping the fiscal agenda in focus as Nigeria turns 52. Paying taxes.

[12]. Sanni, A. U. (2007). Tax reforms in the capital Market: A welcome development. Seminar Paper, Ogun State Internal Revenue Service's Seminar, Ogun State, Nigeria.

[13]. The World Bank (1997). Job generation and growth decomposition tool: Understanding the sectoral pattern of growth and its employment and productivity intensity. Poverty Reduction and Economic Management (PREM). World Bank. Version 1.0.

[14]. Worlu, C. N. \& Emeka, N. (2012). Tax revenue and economic development in Nigeria: A macroeconometric approach. Academic Journal of Interdisciplinary Studies. Published by MCSER-CEMAS-Sapienza University of Rome. (1): 2. ISSN 2281-3993. 